\title{
Sexual and Reproductive Health Services Utilization and Associated Factors Among Preparatory School Students in Mecha District, Northwest Ethiopia: Cross Sectional Study
}

\author{
Alehegn Bishaw Geremew ${ }^{2}$, Mulunesh Tesfa Tsega ${ }^{1 *}$, Yilkal Tiruneh Ayele ${ }^{1}$ and Abebaw Addis Gelagay ${ }^{2}$
} ${ }^{1}$ Amhara Regional Health Bureau, Ethiopia

${ }^{2}$ Department of Reproductive Health, College of Medicine and Health Sciences, University of Gondar, Ethiopia

Submission: May 23, 2018 ; Published: September 19, 2018

*Corresponding author: Alehegn Bishaw Geremew, Principal Investigator, Amhara Regional Health Bureau, Bahir Dar, Ethiopia; Email: muluneshtesfa2006@gmail.com

Abstract

Background: Most of adolescents' sexual and reproductive health problems can be alleviated through sexual and reproductive health services. However, information about the level of sexual and reproductive health services utilization is limited. Additionally, the level of service utilization varies from place to place. Therefore, this study aimed to assess sexual and reproductive health services utilization and its associated factors among preparatory school students in Mecha district, northwest Ethiopia.

Methods: Institutional based cross-sectional study was conducted on September, 2015 among preparatory school students. The data were entered into Epi Info version 3.5.1 and transferred to SPSS version 20 for analysis. Descriptive, bivariate and multivariable analyses were done. Odds ratio with $95 \%$ confidence interval were used to assess the presence and the strength of association.

Results: Reproductive health services utilization among preparatory school students in Mecha district was 18.4\% (95\%CI: 15.2\%-21.9\%). In the pooled multivariate analysis, having employed mother, having discussion with their families on sexual matters, having sexual exposure, and involving in school sexual and reproductive health clubs or school mini-media were significantly associated with sexual and reproductive health services utilization. Having personal income or pocket money was an additional factor which was positively associated with sexual and reproductive health service utilization among male adolescents but not statistically significant among female adolescents.

Conclusion: In this study, utilization of sexual and reproductive services by preparatory school students was low. Parents, school staffs, and health professionals have great impact on adolescents' sexual and reproductive health service utilization.

Keywords: Reproductive health; Students; Utilization; Ethiopia

Abbreviations: AIDS: Acquired Immuno-Deficiency Syndrome; AOR: Adjusted Odds Ratio; BOFED: Bureau of Finance and Economic Development; BSc: Bachelor Science; EDHS: Ethiopian Demographic and Health Survey; HIV: Human Immuno-deficiency Virus; ICPD: International Conference for Population and Development; SRH: Reproductive Health; SRH: Sexual and Reproductive Health; STI: Sexually Transmitted Infection; SD: Standard Deviation; UN: United Nation; USD: United State Dollar; WHO: World Health Organization

\section{Introduction}

Adolescent is an individual aged from 10-19 years. Adolescence is a period of transition from childhood to adulthood. There are more than 1.2 billion adolescents in world and most of them are living in developing countries. Globally, around 25\% (more than1.8 billion) of world population are young, aged 1024 years. The proportion is high in developing countries. In Ethiopia, they account $35 \%$ of the total population [1].

Adolescence, when major physical and psychosocial changes occur, is both a time of opportunity and risks [2]. Though most adolescents are healthy, there is a significant number of adolescent deaths, illness, and diseases. Sexual and reproductive health problems due to unprotected sex attribute a significant proportion of adolescent morbidities and mortality [3]. These SRH problems include Human Immuno-deficiency Virus (HIV) infection, other sexually transmitted infections, and complications of pregnancy, childbirth and abortion. Adolescent boys and girls are disproportionately affected by HIV more importantly in developing countries like Sub-Saharan countries $[3,4]$. All these problems can be preventable through sexual and reproductive health services up take. Though the level of the problem varies from place to place, different studies noted that adolescents/youths have experienced social, psychological, and accessibility (financial, geographical, and cognitive) problems that hinder the uptake of SRH services when the need arises [58]. 
Youth-friendly services should be accessible, acceptable and appropriate to the needs of young people. The World Health Organization (WHO) definition of youth-friendly services requires that such services should be in the right place, at the right time, at the right price and delivered in the right style to be acceptable to young people. In addition, the services should be effective, safe and able to meet the individual needs of young people - who will then return when they need to and recommend these services to friends [4].

Many countries have given due attention to the problems of youth and adolescents after the declaration of international year of youth by United Nation (UN) in 1985 and the Cairo1994 International Conference for Population and Development (ICPD). The accessibility to and utilization of sexual and reproductive health services among youths are a global concern [9]. A range of comprehensive SRH services being provided for youths and adolescents in Ethiopia are: information and counseling on SRH issues, and sexuality, family planning counseling and methods, condom promotion and provision, pregnancy tests, HIV counseling and testing, management of sexually transmitted infections, antenatal care, delivery services, postnatal care, prevention of mother to child transmission of HIV, abortion and post abortion care $[10,11]$. Government of Ethiopia has given attention and is working to address the various sexual and reproductive health needs of adolescent and youths by increasing accessibility of and promoting youth friendly health services in every health center.

However, there is limited information regarding the level of sexual and reproductive health services utilization and factors associated with service utilization in the study area and even in Ethiopia. Additionally, big variation was observed on the level of SRH service utilization from place to place in Ethiopia (80.5 $\%$ in Madawalbu [12] and 21.5\% in east Gojjam [8]). Therefore, it was important to conduct a study to assess sexual and reproductive health services utilization and associated factors among preparatory and high school students in Mecha district, northwest Ethiopia and came up with recommendations. Which in turn is important to design strategies and to take appropriate interventions.

\section{Methods}

\section{Study design, study area and period}

Institution based cross sectional study was conducted to assess the sexual and reproductive health services utilization and associated factors among preparatory school students. The study was conducted on September 2015 in Mecha district, northwest Ethiopia. It is located $529 \mathrm{Km}$ far from Addis Ababa (capital city of Ethiopia) to northwest. According to the Amhara regional bureau of finance and economic development (BOFED) 2015 report, the district has 46 Kebeles ( 6 urban and 40 rural) with a total of 370,032 population.

\section{Study population}

All preparatory school youth students at Mecha district were the study population. Students who attend their academy at least for six month in the district school were included in the study.

\section{Sample size determination and Sampling procedure}

The sample size was computed by using single population proportion formula for the first objective by considering the following assumption: Prevalence of SRH service utilization $=32 \%$ (a study done in Bahir Dar), level of significance (a) $=5 \%$, $4 \%$ marginal error, and $10 \%$ for non-response rate, the sample size was 574. For the second objective, the sample size was determined by using Open Epi software by considering the above assumptions. Since all the sample size computed for the second objective were less than the sample size calculated for the first objective, 574 was taken as a final sample size.

In Mecha district, there was only one preparatory school having a total of 2453 students. The sample size was proportionally allocated to grade 11 students (318 from 1359) and 12 students ( 256 from 1094). By taking the list of all students in each grade, the investigators developed sampling frame. Then simple random sampling technique (computer generated random sampling) was used to select the study participants from each grade.

\section{Operational definitions}

SRH Service utilization: Utilization of one or more of the following sexual and reproductive health services: HIV counseling and testing, STI screening and treatment, family planning counseling and contraceptive use, life skill education, condom use, abortion service, and perinatal services within the last one year.

Knowledge on sexual and reproductive health services: Those who mention at list two SRH services and at least one source of SRH services.

Sexual exposure/practice: Having at least one sexual contact within the last one year.

\section{Data collection}

The questionnaire was first prepared in English and then translated to local language, Amharic, and re-translated back to English by language experts. Four diploma nurses for data collection and one Bachelor Science (BSc) nurse for supervision were recruited and were given training on the tool and the procedure by investigators. The tool was tested on 30 in school students at Bahir Dar city. Some modification was made on the tool after the pretest.

The data collectors obtained the consent after they read the information sheet and then they requested students to give the required information. Data on demographic factors, socio-economic factors, sexual and reproductive health related information and behavior, and sexual and reproductive health service utilization were collected using self-administered questionnaire. The supervisor and investigators supervised the data collection process. 


\section{Data processing and analysis}

The data were checked manually for completeness first and be coded. Questionnaires which were incomplete for major variable/s have been excluded from the study. The data were entered in to EPI Info version 3.5.1 and were transferred to SPSS version 20 and STATA version 14 for analysis. Descriptive statistics was done to describe the study participants. Binary logistic regression model was used to analyze the data. Firstly, bivariate analysis was employed to see the association of each variable to the outcome variable. Two multivariate analysis models were used to see the independent effect of each explanatory variables with the outcome variable. The first multivariate analysis model was a pooled analysis to identify the factors associated with sexual and reproductive health service utilization in the overall study population while the second multivariate analysis model was to identify factors associated with the outcome variable stratified by sex/gender. In multivariate analysis, variables having P-value less than 0.05 were considered as significantly associated with the outcome variable. Adjusted odds ratio (AOR) with 95\% CI was used to determine the presence and the strength of association.

\section{Ethical considerations}

Ethical clearance was first obtained from of University of Gondar, College of Medicine and the Health Science, Institute of Public Health, Institutional Review Board (IRB). Support letter was obtained from the Amhara Regional Education Bureau and then from Mecha district education office and permission was obtained from Merawi preparatory school director office. Informed consent/assent was obtained before conducting data collection. They were also informed about their right not to participate or withdraw from the study at any time. The data were collected anonymously so as to keep the confidentiality of the information.

\section{Results}

\section{Demographic and socioeconomic characteristics of the study participants}

Table 1: Demographic and socioeconomic characteristics of preparatory school students in Mecha district, northwest Ethiopia, 2015.

\begin{tabular}{|c|c|c|c|}
\hline \multicolumn{2}{|c|}{ Variable } & $\begin{array}{c}\text { Frequency } \\
(\mathbf{n = 5 6 5 )}\end{array}$ & Percentage \\
\hline \multirow{3}{*}{ Sex } & Male & 260 & 46 \\
\cline { 2 - 4 } & Female & 305 & 54 \\
\hline \multirow{3}{*}{ Age } & $15-19$ years & 341 & 60.4 \\
\cline { 2 - 4 } & $20-24$ years & 224 & 39.6 \\
\hline \multirow{3}{*}{ Residence } & Urban & 486 & 86 \\
\cline { 2 - 4 } & Rural & 79 & 14 \\
\hline \multirow{3}{*}{ Marital status } & Married & 30 & 5.3 \\
\cline { 2 - 4 } & Not married & 533 & 94.3 \\
\cline { 2 - 4 } & Divorced & 2 & 0.4 \\
\hline
\end{tabular}

\begin{tabular}{|c|c|c|c|}
\hline \multirow{2}{*}{$\begin{array}{l}\text { Educational } \\
\text { status of } \\
\text { respondent's } \\
\text { mother }\end{array}$} & $\begin{array}{l}\text { No formal } \\
\text { education }\end{array}$ & 464 & 82.1 \\
\hline & $\begin{array}{c}\text { Primary school } \\
\text { and above }\end{array}$ & 101 & 18 \\
\hline \multirow{2}{*}{$\begin{array}{l}\text { Educational } \\
\text { status of } \\
\text { respondent's } \\
\text { father }\end{array}$} & $\begin{array}{l}\text { No formal } \\
\text { education }\end{array}$ & 341 & 60.4 \\
\hline & $\begin{array}{c}\text { Primary school } \\
\text { and above }\end{array}$ & 224 & 39.6 \\
\hline \multirow[t]{2}{*}{ Living status } & $\begin{array}{l}\text { Living with } \\
\text { parents and } \\
\text { other relatives }\end{array}$ & 362 & 64.1 \\
\hline & Living alone & 203 & 35.9 \\
\hline \multirow{2}{*}{$\begin{array}{c}\text { Personal } \\
\text { income or } \\
\text { pocket money }\end{array}$} & Yes & 351 & 62.1 \\
\hline & No & 214 & 37.9 \\
\hline \multirow{4}{*}{ Family incomea } & $</=50$ & 199 & 35.2 \\
\hline & $51-100$ & 193 & 34.2 \\
\hline & $101-150$ & 73 & 12.9 \\
\hline & $>150$ & 100 & 17.7 \\
\hline
\end{tabular}

${ }^{\mathrm{a}}$ Family income is in USD

In this study, a total of 565 students were considered for analysis. Three respondents were absent during data collection time and six questionnaire were excluded because of data incompleteness. The mean age of the study participants was 19.2 years ( $\mathrm{SD} \pm 1.24$ years). More than half of the respondents, 305 (54\%), were female. Most respondents, 533 (94.3\%) were not married and $362(64.1 \%)$ were living with their parents. Regarding to personal income or pocket money, 351(62.1\%) of the respondents had personal income or pocket money. About a third (35.2\%) of respondent's monthly family income was less than or equal to 50 United State Dollar (USD) (Table 1).

\section{Sexual and reproductive health related information and behavior}

Table 2:Sexual and reproductive health related information and behavior of preparatory school students in Mecha district, northwest Ethiopia, 2015

\begin{tabular}{|c|c|c|c|}
\hline Variables & Response & Frequency & Percent \\
\hline $\begin{array}{c}\text { Respondents } \\
\text { who heard } \\
\text { about SRH }\end{array}$ & Yes & 550 & 97.3 \\
\cline { 2 - 4 } & No & 15 & 2.7 \\
\hline Respondents & Yes & 376 & 66.5 \\
\hline $\begin{array}{c}\text { knowledge on } \\
\text { SRH }\end{array}$ & No & 189 & 35.5 \\
\hline \multirow{2}{*}{$\begin{array}{c}\text { Source of Infor- } \\
\text { mation }\end{array}$} & Teachers & 107 & 76.54 \\
\cline { 2 - 4 } & Media & 105 & 19.45 \\
\cline { 2 - 4 } & Parents & 87 & 19 \\
\cline { 2 - 4 } & Peers /friends & 53 & 16.6 \\
\hline \multirow{2}{*}{$\begin{array}{c}\text { Discussion on } \\
\text { SRH issues } \\
\text { with peer }\end{array}$} & Yes & 95 & 83.2 \\
\cline { 2 - 4 } & No & 470 & 16.8 \\
\hline
\end{tabular}




\begin{tabular}{|c|c|c|c|}
\hline Discussion on & Yes & 181 & 32 \\
\cline { 2 - 4 } $\begin{array}{c}\text { SRH issues } \\
\text { with families }\end{array}$ & No & 384 & 68 \\
\hline $\begin{array}{c}\text { Involvement in } \\
\text { SRH clubs/mini } \\
\text { media }\end{array}$ & Yes & 245 & 43.4 \\
\cline { 2 - 4 } & No & 320 & 56.6 \\
\hline $\begin{array}{c}\text { Sexual expo- } \\
\text { sure }\end{array}$ & Yes & 90 & 16 \\
\cline { 2 - 4 } & No & 475 & 84 \\
\hline
\end{tabular}

Almost all, 550 (97.3\%), of the respondents had awareness about SRH services. Health professionals, 421(76.5\%), were the main source of information. From the total study participants, $470(83.2 \%)$ and $384(68 \%)$ respondents had no discussion on SRH issues with their peers and their families respectively (Table 2).

\section{Level of sexual and reproductive health service utili- zation}

From the total participants, only 104 (18.4\%) (95\%CI: 15.2$21.9 \%$ ) used SRH services within the last one year. Among the total sexual and reproductive health service users, more than half, 63 (60.57\%), had used voluntary counseling and testing (VCT) services for HIV (Figure 1). Among the study participants who had sexual contact in the past one year, only 37(41\%) used contraceptive methods. Regarding the method mix: 13 (14.4\%) used condom, 14 (15.6\%) used oral pill, 10 (11\%) used injectable, $7(7.8 \%)$ used emergency pill and $4(4.4 \%)$ used implant. Among contraceptive users, 11 (12.2\%) used dual methods. Most SRH service users, 72 (69\%), were handled friendly by health service providers. From the adolescents' perspective, the main obstacles/barriers that refrain them from getting SRH services were inconvenient working hour, 314 (56\%), inconvenient location, 311 (55\%), fear of families, 303 (54\%), and financial barrier, 112 (20\%).

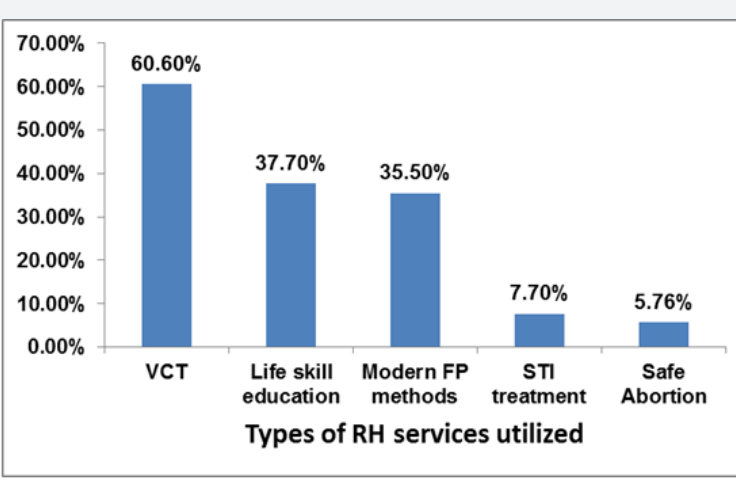

Figure 1:Types of sexual and reproductive health services utilized by preparatory school students in Mecha district, northwest Ethiopia, 2015.

\section{Factors associated with sexual and reproductive health services utilization}

Utilization of sexual and reproductive health services by respondents was assessed with different variables. Considering the two multivariate analysis model, this study showed that having employed mother, discussing on SRH with families, having personal income or pocket money, involving in SRH clubs or school mini-media, and having sexual exposure had statistically significant association with sexual and reproductive health services utilization.

In the pooled multivariate analysis model, respondents who had employed mother were almost two times [AOR=1.74 (95\%CI: 1.07-2.85)] more likely to use SRH service than those whose mother were not employed. Students who had discussed on SRH issues with their families were one point five times [AOR=1.55 (95\%CI: 1.07-2.60)] more likely to use SRH services as compared to students who hadn't discussed. Students who had sexual exposure were nine times [AOR=9.34 (95\%CI: 5.4615.98)] more likely to use SRH services than those who didn't have sexual exposure. Students who were involved in SRH clubs or school mini-media were two times [AOR=1.55(95\%CI: 1.082.55)] more likely to use SRH services than those who were not involved to SRH clubs/school mini-media (Table 3).

Table 3: Bivariate and multivariate analysis of SRH service utilization and associated factors among preparatory school students in Mecha woreda, northwest Ethiopia, 2015.

\begin{tabular}{|c|c|c|c|c|}
\hline \multirow{2}{*}{ Variables } & \multicolumn{2}{|c|}{ SRH service utilization } & \multirow{2}{*}{$\begin{array}{c}\text { COR }(95 \% \\
\text { CI) }\end{array}$} & \multirow{2}{*}{$\begin{array}{c}\text { AOR }(95 \% \\
\text { CI) }\end{array}$} \\
\hline & Yes & No & & \\
\hline \multicolumn{5}{|c|}{ Age } \\
\hline $15-19$ & 62 & 279 & 1 & 1 \\
\hline $20-24$ & 42 & 182 & $\begin{array}{c}1.04(0.67- \\
1.60)\end{array}$ & $\begin{array}{c}0.88(0.52- \\
1.50)\end{array}$ \\
\hline \multicolumn{5}{|c|}{ Sex } \\
\hline Male & 47 & 213 & $\begin{array}{c}0.96(0.63- \\
1.47)\end{array}$ & $\begin{array}{c}0.87(0.51- \\
1.47)\end{array}$ \\
\hline Female & 57 & 248 & 1 & 1 \\
\hline \multicolumn{5}{|c|}{ Residence } \\
\hline Urban & 92 & 394 & $\begin{array}{c}1.30(0.68- \\
2.51)\end{array}$ & $\begin{array}{c}1.28(0.61- \\
2.71)\end{array}$ \\
\hline Rural & 12 & 67 & 1 & 1 \\
\hline \multicolumn{5}{|c|}{ Mother's education } \\
\hline $\begin{array}{c}\text { Has no } \\
\text { formal } \\
\text { education }\end{array}$ & 86 & 378 & 1 & 1 \\
\hline $\begin{array}{l}\text { Primary } \\
\text { school and } \\
\text { above }\end{array}$ & 18 & 83 & $\begin{array}{c}0.95(0.54- \\
1.67)\end{array}$ & $\begin{array}{c}1.09(0.55- \\
2.17)\end{array}$ \\
\hline \multicolumn{5}{|c|}{ Father's education } \\
\hline $\begin{array}{l}\text { Has no } \\
\text { formal } \\
\text { education }\end{array}$ & 60 & 281 & 1 & 1 \\
\hline $\begin{array}{l}\text { Primary } \\
\text { school and } \\
\text { above }\end{array}$ & 44 & 180 & $\begin{array}{c}1.14(0.74- \\
1.76)\end{array}$ & $\begin{array}{c}1.28(0.75- \\
2.18)\end{array}$ \\
\hline \multicolumn{5}{|c|}{ Living condition } \\
\hline $\begin{array}{l}\text { Living with } \\
\text { parents/ } \\
\text { relatives }\end{array}$ & 64 & 298 & 1 & 1 \\
\hline Living alone & 40 & 163 & $\begin{array}{c}1.14(0.74- \\
1.77)\end{array}$ & $\begin{array}{c}0.73(0.30- \\
1.77)\end{array}$ \\
\hline
\end{tabular}




\section{Journal of Gynecology and Women's Health}

\begin{tabular}{|c|c|c|c|c|}
\hline \multicolumn{5}{|c|}{ Personal income (pocket money) } \\
\hline Yes & 45 & 169 & $\begin{array}{c}1.32(0.86- \\
2.03)\end{array}$ & $\begin{array}{c}1.26(0.53- \\
3.00)\end{array}$ \\
\hline No & 59 & 292 & 1 & 1 \\
\hline \multicolumn{5}{|c|}{ Family monthly income ${ }^{a}$} \\
\hline$>/=50$ & 39 & 160 & 1 & 1 \\
\hline $51-100$ & 32 & 161 & $\begin{array}{c}0.82(0.49- \\
1.37)\end{array}$ & $\begin{array}{c}0.63(0.34- \\
1.15)\end{array}$ \\
\hline $101-150$ & 16 & 57 & $\begin{array}{c}1.15(0.59- \\
2.22)\end{array}$ & $\begin{array}{c}1.16(0.55- \\
2.45)\end{array}$ \\
\hline$>150$ & 17 & 83 & $\begin{array}{c}0.84(0.45- \\
1.56)\end{array}$ & $\begin{array}{c}0.65(0.31- \\
1.37)\end{array}$ \\
\hline \multicolumn{5}{|c|}{ Mother's occupation } \\
\hline Employed & 51 & 159 & $\begin{array}{c}1.83(1.19- \\
2.81)\end{array}$ & $\begin{array}{c}1.74(1.07- \\
2.85)^{*}\end{array}$ \\
\hline House wife & 53 & 302 & 1 & 1 \\
\hline \multicolumn{5}{|c|}{ Father's occupation } \\
\hline Farmer & 92 & 391 & 1 & 1 \\
\hline Employee & 3 & 30 & $\begin{array}{c}0.43(0.13- \\
1.42)\end{array}$ & $\begin{array}{c}0.47(0.12- \\
1.84)\end{array}$ \\
\hline $\begin{array}{c}\text { Private } \\
\text { Business }\end{array}$ & 9 & 40 & $\begin{array}{c}0.96(0.45- \\
2.04)\end{array}$ & $\begin{array}{c}0.87(0.34- \\
2.24)\end{array}$ \\
\hline \multicolumn{5}{|l|}{$\begin{array}{l}\text { Awareness } \\
\text { about SRH }\end{array}$} \\
\hline Yes & 103 & 447 & $\begin{array}{c}3.23(0.42- \\
24.81)\end{array}$ & $\begin{array}{c}1.92(0.23- \\
16.28)\end{array}$ \\
\hline No & 1 & 14 & 1 & 1 \\
\hline \multicolumn{5}{|c|}{ Discussion with peers on SRH } \\
\hline Yes & 28 & 67 & $\begin{array}{c}2.17(1.31- \\
3.59)\end{array}$ & $\begin{array}{c}1.72(0.94- \\
3.15)\end{array}$ \\
\hline No & 76 & 394 & 1 & 1 \\
\hline \multicolumn{5}{|c|}{ Discussion with families on SRH } \\
\hline Yes & 46 & 135 & $\begin{array}{c}1.92(1.24- \\
2.96)\end{array}$ & $\begin{array}{c}1.55(1.07- \\
2.60)^{*}\end{array}$ \\
\hline No & 58 & 326 & 1 & 1 \\
\hline \multicolumn{5}{|c|}{ Involvement in SRH clubs } \\
\hline Yes & 57 & 188 & $\begin{array}{c}1.76(1.15- \\
2.70)\end{array}$ & $\begin{array}{c}1.55(1.08- \\
2.55)^{*}\end{array}$ \\
\hline No & 47 & 273 & 1 & 1 \\
\hline \multicolumn{5}{|c|}{ Sexual exposure } \\
\hline Yes & 49 & 41 & $\begin{array}{c}9.13(5.53- \\
15.06)\end{array}$ & $\begin{array}{c}9.34(5.46- \\
15.98)^{* *}\end{array}$ \\
\hline No & 55 & 420 & 1 & 1 \\
\hline
\end{tabular}

Note: $1=$ Reference, ${ }^{*} \mathrm{P}$-value $<0.05{ }^{* *} \mathrm{P}$-value $<0.001$, Hosmer and Lemeshow Test $=0.245$.

In the second multivariate analysis model, different factors were associated with the outcome variable. In male students, the odds of using SRH services were 3.6 (95\%CI: 1.04-12.51) times higher in those who had personal income or pocket money than their counterparts. Male students who had discussed with their families on SRH matters were 2.47 times [AOR=2.47 (95\% CI: 1.15-6.08)] more likely to use SRH services as compared to those who hadn't discussed. Male students who were involved in school sexual and reproductive health clubs or school mini-media were 1.45 times [AOR=1.45 (95\%CI: 1.04-2.28)] more likely to use SRH services as compared to those who were not involved in school sexual and reproductive health clubs or school mini-media. Male students who had sexual exposure were 11.10 times [AOR=11.10 (95\%CI: 4.74-25.99)] more likely to use SRH services as compared to those who didn't have sexual exposure (Table 4).

Table 4: Multivariate analysis of factors associated with sexual and reproductive health services utilization stratified by sex among preparatory school students in Mecha woreda, northwest Ethiopia, 2015.

\begin{tabular}{|c|c|c|}
\hline \multirow{2}{*}{ Variables } & Male & Female \\
\hline & AOR $(95 \% \mathrm{CI})$ & AOR $(95 \% \mathrm{CI})$ \\
\hline \multicolumn{3}{|c|}{ Age } \\
\hline $15-19$ & 1 & 1 \\
\hline $20-24$ & $0.99(0.44-2.22)$ & $0.68(0.30-1.51)$ \\
\hline \multicolumn{3}{|c|}{ Residence } \\
\hline Urban & $3.07(0.74-12.68)$ & $0.89(0.34-2.30)$ \\
\hline Rural & 1 & 1 \\
\hline \multicolumn{3}{|c|}{ Mother's education } \\
\hline $\begin{array}{l}\text { Has no formal edu- } \\
\text { cation }\end{array}$ & 1 & 1 \\
\hline $\begin{array}{l}\text { Primary school and } \\
\text { above }\end{array}$ & $0.74(0.25-2.24)$ & $1.42(0.57-3.56)$ \\
\hline \multicolumn{3}{|c|}{ Father's education } \\
\hline $\begin{array}{l}\text { Has no formal edu- } \\
\text { cation }\end{array}$ & 1 & 1 \\
\hline $\begin{array}{l}\text { Primary school and } \\
\text { above }\end{array}$ & $1.24(0.51-2.98)$ & $1.59(0.77-3.18)$ \\
\hline \multicolumn{3}{|c|}{ Living condition } \\
\hline $\begin{array}{l}\text { Living with parents/ } \\
\text { relatives }\end{array}$ & 1 & 1 \\
\hline Living alone & $0.31(0.08-1.14)$ & $1.41(0.42-4.71)$ \\
\hline \multicolumn{3}{|c|}{ Personal income (pocket money) } \\
\hline Yes & $3.60(1.04-12.51)^{*}$ & $0.57(0.17-1.94)$ \\
\hline No & 1 & 1 \\
\hline \multicolumn{3}{|c|}{ Family monthly income ${ }^{a}$} \\
\hline$>/=50$ & 1 & 1 \\
\hline $51-100$ & $0.49(0.19-1.27)$ & $0.73(0.32-1.68)$ \\
\hline $101-150$ & $2.04(0.69-5.98)$ & $0.73(0.24-2.26)$ \\
\hline$>150$ & $0.68(0.19-2.44)$ & $0.68(0.25-1.82)$ \\
\hline \multicolumn{3}{|c|}{ Mother's occupation } \\
\hline Employed & $1.41(0.65-3.02)$ & $2.05(1.04-4.05)^{*}$ \\
\hline House wife & 1 & 1 \\
\hline \multicolumn{3}{|c|}{ Father's occupation } \\
\hline Farmer & 1 & 1 \\
\hline Employee & $0.78(0.12-4.93)$ & $0.17(0.02-1.65)$ \\
\hline Private Business & $0.63(0.13-3.13)$ & $1.52(0.45-5.19)$ \\
\hline \multicolumn{3}{|c|}{ Discussion with peers } \\
\hline Yes & $1.85(0.82-4.18)$ & $1.17(0.47-2.92)$ \\
\hline No & 1 & 1 \\
\hline
\end{tabular}




\begin{tabular}{|c|c|c|}
\hline \multicolumn{3}{|c|}{ Discussion with families } \\
\hline Yes & $2.47(1.15-6.08)^{*}$ & $1.43(1.06-2.98)^{*}$ \\
\hline No & 1 & 1 \\
\hline \multicolumn{3}{|c|}{ Involvement in SRH clubs } \\
\hline Yes & $1.45(1.04-2.28)^{*}$ & $2.36(1.17-4.77)^{*}$ \\
\hline No & 1 & 1 \\
\hline \multicolumn{3}{|c|}{ Sexual exposure } \\
\hline Yes & $11.10(4.74-25.99)^{* *}$ & $11.27(5.17-24.59)^{* *}$ \\
\hline No & 1 & 1 \\
\hline
\end{tabular}

In female students, the odds of using SRH services were 2.05 times [AOR= 2.05 (95\% CI: 1.14-4.05)] higher in those who had employed mother than those whose mother were housewife. The odds of using SRH services were 1.43 times [AOR=1.43 (95\%CI: 1.06-2.98)] higher in female students who had discussed with their families on SRH issues as compared to female students who hadn't discussed. Female students who were involved in sexual and reproductive health clubs or school mini-media were 2.36 times $[\mathrm{AOR}=2.36$ (95\%CI: 1.17-4.77)] more likely to use SRH services as compared to those who were not involved in sexual and reproductive health clubs or school mini-media. Female students who had sexual exposure were 11.27 times [AOR= 11.27 (5.17-24.59)] more likely to use SRH services as compared to those hadn't sexual exposure (Table 4).

\section{Discussion}

Information about sexual and reproductive health services is a prerequisite for SRH service utilization. Majority of the students had awareness about the sexual and reproductive health service. Health professionals, teachers and media were the main source of information. Utilization of sexual and reproductive health services among preparatory school students in Mecha district was $18.4 \%$. In the multivariate analysis, open discussion with parents/families, having employed mother, involving in SRH clubs/mini-media, having personal income/pocket money, and having sexual exposure were positively associated with sexual and reproductive health service utilization.

Less than one-fifth (18.4\%) of preparatory school students in Mecha district utilized sexual and reproductive health services. This finding was almost consistent with the study done in Mekele (22\%) [13], and in Machakel district, east Gojam zone (21.5\%) [8]. However, it was lower as compared to studies conducted in Harare (63.8\%) [14] and Bihar Dar (32\%) [7]. This finding was also lower than the studies done in Awabel district, Ethiopia [15] and in Nigeria [16] that SRH service utilization six months preceding the data collection time was $41.2 \%$ and $29.7 \%$ respectively. This difference might be due to difference in age and maturation. For example, in Madawalbu, the study was conducted among University students whose age and maturation are relatively higher than study participants in this study. Additionally, university students are relatively free from family and community influences; there may be high peer influence and risk perception in university students. All these might made difference in SRH services utilization. In the studies done in
Harare town and Awabel district, the studies were conducted on out of school students that most of them might have sexual exposure and might be married. Socio-demographic variation might be another possible reason for this variation $[17,18]$.

Sexual and reproductive health service (SRH) utilization was affected by different factors. In this study, students who had employed mother were two times more likely to use SRH services than those who had non-employed mother. This might be due to the fact that employed mothers may have better information or awareness about SRH issues and might have open communication with their children. This can create good opportunity for adolescents to think and give high value for their sexual and reproductive health and to obtain SRH services. The same association was also seen in a study done in Kenya [19]. However, in the second multivariate analysis model, it was identified that male students who had employed mother had no statistically significant association with SRH service utilization as compared to their counterparts. This might be due to the fact that mothers give more attention for girls in providing information and making open discussion on SRH matters because of relatively high burden of SRH problems in females.

In this study, open discussion about sexual and reproductive health with parents was significantly associated with students' SRH service utilization. This might be due to the fact that parent and child relationship might influence young people's decision to use different SRH services. Moreover, sexual and reproductive health communication is mostly promote healthy sexual development and reduce sexual risks. Communication is the principal means for parents to transmit sexual values, beliefs, expectations and knowledge to their adolescents. Thus, adolescents are more likely to engage in healthy behaviors when they feel connected to their family, and it also creates opportunity to deal with adolescent problems related to their SRH and services. The same finding was seen in studies done in Gondar, East Gojam zone, and Awabel district, Ethiopia [8,15,17], Nigeria [16], and United State [20].

In this study, the study participants who had sexual practice were 9 times more likely to use SRH services than abstainers. This could be due to difference in risk perception. Adolescents who had sexual contact might relatively have high level of risk perception for unwanted pregnancy, abortion, HIV and other STIs than those who abstain. So, they might plan and use methods of protection during sexual activity. The same finding was also seen in the study conducted in Madawalbu, Awabel district, and Gondar town, Ethiopia [12,15,17].

Involvement in school SRH clubs or school mini-media was positively associated with SRH service utilization. Students who were a member of school SRH clubs or school mini-media might frequently discuss on sexual and reproductive health issues, on the barriers to utilization of services, on sexual and reproductive health risks, develop life skills, share experiences and have awareness. Hence, this can increase SRH service utilization. 
Male students who had personal income or pocket money had better SRH service uptake than their counterparts. The reason might be when male students have access to money they may be engaged in sexual activity that demands to use SRH services. However, this association was not observed in female students and in the overall (pooled) multivariate analysis.

The strength of this study might be addressing one of the government's thematic areas of research and intervention. In this study, out school youths were not addressed. This is the possible limitation of this study.

\section{Conclusion}

Sexual and reproductive health service utilization among preparatory school students in Mecha woreda was low. This might make adolescents prone for different sexual and reproductive risks/problems. This in turn can increase school dropout rate and has impact on their future life. It also causes failure of adolescent health policy from meeting its goal. Discussing on SRH with parents; having employed mothers; involving in $\mathrm{RH}$ clubs or school mini-media, and having sexual exposure were found as predictors for SRH service utilization. This implies that improving the cogitative accessibility of SRH is mandatory. That is, providing information, education and communication about risky sexual practices, sexual and reproductive health and services, and breaking the social barriers are found imperative. So, parents/families, school staffs, and health professionals are important stake holders to improve SRH services utilization.

\section{Declarations}

\section{Data availability}

All data generated or analyzed during this study are included in this main manuscript

\section{Competing interests}

The authors declared that there are no financial and nonfinancial competing interests.

\section{Author's contributions}

MTT designed the study and acquired the data; MTT, AAG and YTA analyzed and interpreted the data. All authors prepared, reviewed and approved the manuscript.

\section{Acknowledgement}

The authors would like to thank University of Gondar for ethical clearance. The authors have special gratitude for data collectors and supervisor for their dedicated work. Finally, special appreciation is forwarded to study participants for their valuable information. Lastly, the authors would like acknowledge Ethiopian Public Health Association (EPHA) for their acceptance of this study for the 28th EPHA annual conference held on February 19-22, 2017 at Harar, Ethiopia.

\section{References}

1. (2013) Population Reference Bureau: The World's Youth 2013 data sheet.
2. WHO (1999) Programming for adolescent health and development: report of a WHO/UNFPA/UNCEF. WHO technical report series 886, Geneva.

3. WHO (2016) Adolescents: health risks and solutions, Fact sheet.

4. UNFPA (2014) Adolescent sexual and reproductive health.

5. Biddlecom AE, Munthali A, Susheela S, Vanessa W (2007) Adolescents' views of and preferences for sexual and reproductive health services in Burkina Faso, Ghana, Malawi and Uganda. African journal of reproductive health 11(3): 99-100.

6. Regmi PR, Teijlingen EV, Simkhada P, Acharya DR (2010) Barriers to Sexual Health Services for Young People in Nepal. J Health Popul Nutr 28(6): 619-627.

7. Meskerem A, Worku A (2014) Utilization of Youth Reproductive Health Services and Associated Factors among High School Students in Bahir Dar, Amhara Regional State, Ethiopia. Open Journal of Epidemiology 4: 69-75.

8. Abajobir AA, Seme A (2014) Reproductive health knowledge and services utilization among rural adolescents in east Gojjam zone, Ethiopia: a community-based cross-sectional study BMC Health Serv Res 14: 138.

9. WHO (2014) Health for the World's Adolescents: A second chance in the second decade.

10. Human Development Resource Center (HDRC) Ethiopia (2011) Adolescent Reproductive Health in Ethiopia.

11. Health FDRoEMo. Standards, and Minimum Service Delivery Package on Youth Friendly Reproductive Health (YFRH) Services.

12. Dida N, Darega B, Takele A (2015) Reproductive health services utilization and its associated factors among Madawalabu University students, Southeast Ethiopia: cross-sectional study. BMC Research Notes 8: 8.

13. Bilal SM, Spigt M, Dinant GJ, Blanco R (2015) Utilization of Sexual and Reproductive Health Services in Ethiopia Does it affect sexual activity among high school students? Sex Reprod Healthc 6(1): 14-18.

14. Motuma A (2012) Youth friendly Health Services Utilization and Factors in Harar, Ethiopia. Harar Bulletin of Health Sciences.

15. Ayehu A, Kassaw T, Hailu G (2016) Level of Young People Sexual and Reproductive Health Service Utilization and Its Associated Factors among Young People in Awabel District, Northwest Ethiopia. PLoS One 11(3): e0151613.

16. Abiodun O, Olu-Abiodun O, Ani F, Sotunsa O (2016) Sexual and Reproductive Health Knowledge and Service Utilization among Inschool Rural Adolescents in Nigeria. J AIDS Clin Res 7: 576.

17. Feleke, Koye DN, Demssie AF, Mengesha ZB (2013) Reproductive Health Service Utilization and Associated Factors among Adolescents (15-19 Years Old) in Gondar Town, Northwest Ethiopia. BMC Health Services Research 13: 294.

18. Naasegnibe K, Paulkwame N, Yazeed A (2012) Utilization of reproductive health services in Ghana.

19. Akinyi, Obonyo P (2013) Determinants of Utilization of Youth Friendly Reproductive Health Services among School and College Youth in Thika west district, Kiambu county, Kenyatta Universtiy Instituional Repository Kenya.

20. Hall KS, Moreau C, Trussell J (2012) Associations Between Sexual and Reproductive Health Communication and Health Service Use Among US Adolescent Women. Perspect Sex Reprod Health 44(1): 6-12. 
(C) This work is licensed under Creative
Your next submission with Juniper Publishers will reach you the below assets

- Quality Editorial service

- Swift Peer Review

- Reprints availability

- E-prints Service

- Manuscript Podcast for convenient understanding

- Global attainment for your research

- Manuscript accessibility in different formats ( Pdf, E-pub, Full Text, Audio)

- Unceasing customer service

Track the below URL for one-step submission https://juniperpublishers.com/online-submission.php 